\title{
The Possible Protective Role of Amygdaline Against Carbon Tetrachloride (CCL4) Induce Certain Biochemical and Antioxidant Changes in Albino Mice (MDA)
}

\author{
Iqbal Fadel Alwan* and Ammar Mawla Ahmood \\ Ministry of Science and Technology, Iraq, Baghdad, Box, 765 \\ *Corresponding Author: eknalfadhel @ gmail.com
}

\begin{abstract}
The study aims to evaluated the protective effect of Amygdaline compound extracted from apricot seeds on the effectiveness of liver enzymes (ALT, AST, GGT) (alkaline phosphatase (ALP), blirubin) cholesterol and triglycerides and(antioxidant (manol dia aldehid MDA), (glotathuine-Stransters (GST)) on the albino mice treated with carbon tetrachloride were studied 32 male albino mice Swiss albino, (5-8 weeks) and (20-25 gm weight).Amygdaline compound was analyzed by High-performance liquid chromatography technique (HPLC).

Conducted tests on the overlap between the three concentration $(150,250,350 \mathrm{mg} / \mathrm{kgm})$ of aqueous extract of Amygdaline $3.2 \mathrm{mg} / \mathrm{kgm}$ of carbon tetrachloride with interaction included two types of treatment ( $\mathrm{pre}^{-\mathrm{ccl}_{4} \text { and post-ccl }}$ ) through oral dosage and for a period of 14 days.

The study shows that the concentration $350 \mathrm{mg} / \mathrm{kgm}$ is the best concentration of aqueous extract there was used and study suggests that use the concentrations of this focus and fact that the plant is used for human consumption broadly and because it contains the Bio flvenote. [DOI: 10.22401/ANJS.00.2.01]
\end{abstract}

Keywords: Carbon tetrachloride, Amygdaline extracted, Antioxidants, Biochemical changes.

\section{Introduction}

Amygdaline is a bioflavonoid derivative of apricot nuclei. The partial formula of this compound is $\mathrm{C} 20 \mathrm{H} 27 \mathrm{NO} 11$. It has an antioxidant role for its ability to get rid oxygen free radical and protect the cellular molecules from oxidative damage (1).

Apricot kernel contains antioxidants (amygdaline) that protect cells from damage and cancer and contain abundant amounts of minerals and essential vitamins which are important compounds in reducing the risk of infection cancer and help to enhance the immunity of the body and protect the weakness of the immune system associated with aging, where the activation of genes and changes in the biochemical and anti-oxidation (MDA) of the immune cells and reduce the roots free, as well as its importance in the treatment of cancer and its causes and prevent some infections of the liver (2) and (3), and figure (1) shows the chemical composition of the compound amygdaline.

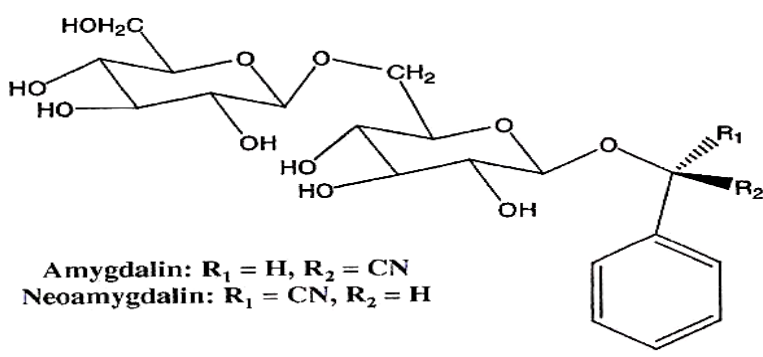

Figure 1 illustrates the molecular formula of the amygdaline compound

Environmental pollutants are harmful to human health and one of the most important problems of the age as the result of industrial progress and increased human activity in the discovery of many chemical compounds, which are used for various purposes including industry pesticides, drugs and chemical industries, including carbon tetrachloride, which is wide-ranging organic compounds and its smell is mild and can be determined even at a few levels. Causes a clear toxicity of the liver through the destruction of its cells or damaged by several mechanisms including necrosis and liver lipid (4).

The increase in the function of liver enzyme occurs as a result of increased cell manufacturing processes or exposure to 
environmental and mutagenic contaminants. There are three different enzymes for liver function is ALT (Alanine amino transferase), AST (Asparatate amino transferase) and GGT (Gamma Glutamyl Transferase), which depend on the integrity of liver cells (3).

Either the extractive capacity of the liver measured using the increased effectiveness of both alkaline phosphatase (ALP) and Bilirubin, (4).

The effect of environmental contaminants (CCL4) lead to a high level of cholesterol and triglycerides due to metabolic disorder of fat, which leads to increase the phosphatosic acid in plasma blood. On the other hand, reference (5) has been noted that the antioxidants lead to an increase in the activity of the enzyme glutathione-S-transferees (GST). This enzyme is a multi-functional enzymes by removing the metabolites of some toxicants and pollutants, including carbon tetrachloride (5).

The harmful effects of environmental pollutants start with the oxidation of unsaturated fatty acids and multiple double bonds, namely, aldehydes, including antioxidant malondialdehyde (MDA), as an initiator of tumors, and as an adjunct to cancer (6).

The purpose of the study was to determine the role of fluophytes in the amygdaline compound by evaluating its protective effect before and after the CCL 4 bioconcentration of laboratory animals by measuring the effectiveness of biochemical changes and antioxidants MDA and GST in serum for laboratory animals.

\section{Materials and Methods}

\section{Materials}

\section{Preparation of the extracted:}

The water extract of the apricot seeds is prepared by the suxatile using a mixing ratio ( $1 \mathrm{~g}: 7.5 \mathrm{ml}$ distilled water). The mixture is then heated for 2 hours after which it is filtered and concentrated and then dried with a cooling device to obtain the amygdaline compound powder (7).

The purity of the amgdaliene compound was measured and compared with a standard model equipped with spulco. Using the shimatza A6 high performance liquid chromatography (HPLC), column type ODS,
C18 and absorbance at a wavelength of 251 $\mathrm{nm}(8)$.

Mobile phase: A composed of non-ionic water + phosphonic acid (1000-1) volume / volumel.

B: Component of Acetonitrile + phosphonic acid (1000-1) volume / volume.

The program of mixing mobile phase solutions during the separation process as it passes through the separation column consists of (min.)-15\%, (20min)-30\%,(25min)-100\%, (45min) $0 \%=\mathrm{B}$ and the mobile phase rate of $1 \mathrm{ml} / 1 \mathrm{~min}$. Absorption is estimated along wavelength (UV.202 nm).

\section{Laboratory animal management:}

The use of 32 male Swiss albino mice at the age of 5-8 weeks and an approximate weight $(20-25 \mathrm{~g})$ were placed in plastic cages, fed with concentrated feed and water, and divided into four groups as follows:

\section{The first group:}

It was composed of four mice and PBS solution was given on the first day and water for 13 days. It was killed on the $14^{\text {th }}$ day by separating cervical vertebrae and negative control.

\section{The second group:}

(4 mice) CCL4 was given at a concentration of $3.2 \mathrm{mg} / \mathrm{kg}$ on the first day orally and then water was given (for thirteen days) and was killed on the $14^{\text {th }}$ day by separating the cervical vertebrae.

\section{The third group:}

This group consisted of 12 mice divided into three groups, CCL4was given at $3.2 \mathrm{mg} /$ $\mathrm{kg}$ orally, and 6 hours later, the water extract of the amygdaline compound was given three concentrates $(150,250,350 \mathrm{mg} / \mathrm{kg}) 14$ days was killed on the fourteenth day by separating cervical vertebrae.

\section{The fourth group:}

This group consisted of 12 mice divided into three groups. The oral extract of amygdaline was given in three concentrations $(150,250,350 \mathrm{mg} / \mathrm{kg})$ for13 days. After that, CCL4 was given a concentration of $3.2 \mathrm{mg} /$ $\mathrm{kg}$ ) $/ 6$ hours) from the end of the thirteenth 
dose and are anatomy at the beginning of the fourteenth day separating cervical vertebrae.

\section{Preparation of blood solution:}

The animals were killed by the cervical displacement and the blood was taken from the heart of the mouse and placed in the tube of the rabbit. And was discarded by centrifugation device at a speed of 3000 cycles / min for 10minutes and used leach ate in the measurement of biochemical changes and antioxidants (9).

\section{Determination of the level and efficiency of enzymes (AST, ALT, GGT):}

The determination of the level of enzyme activity in the serum of laboratory animals was studied. As follows by instructions according to the method mentioned by the company supplied Randox, U.K. (10).

Determination of the effectiveness of cholesterol and triglyceride:

The sample used in this test is a blood serum to determine the effectiveness of cholesterol and triglyceride manner indicated by the company supplied Randox, U.K.

\section{Determination of the level and effectiveness} of the enzyme (Alkaline phosphatase) $(A L P)$ :

To determine the efficiency of alkaline phosphates (ALP) in the serum by measuring the optical density of the solutions along wavelength $(510 \mathrm{~nm})$ using the optical spectrometer (11).
Determination of the level of activity (Billrubin):

The sample used in this test is serum to determine the effectiveness of propane in the color indicated by the company supplied Randox, U.K.

\section{Preparation of the blood solution:}

To determine the effectiveness of the GST enzyme. Kill the animals by cervical displacement, take the blood from the heart and put in a test tube containing an anticoagulant (EDTA) and mix with a $0.9 \%$ saline (10minutes). Leave the leach ate and add $1 \mathrm{ml}$ of distilled water, then mix well and keep $\left(\begin{array}{ll}-20 & \mathrm{C}\end{array}\right)$ until used to measure the enzyme (GST) according to method (12).

Determination of the level (MDA):

The measurement of the diahydide material in the chromatic manner used on wavelength absorption is (532 nm) and method (13)

The results of the efficiency of biochemical changes in serum, GST and MDA were analyzed for variance analysis using the SAS Statistical program (2001). For the lowest significant difference / LSD was used at $(\mathrm{P}<0.05)$ to detect the differences between levels different transactions.

\section{Results and Discussion}

HPLC tests: Figures (2), (3) shows the process of separation of the amygdaline extracted from the high performance liquid chromatography (HPLC) at the time of detention (16.5) $\min (14)$.

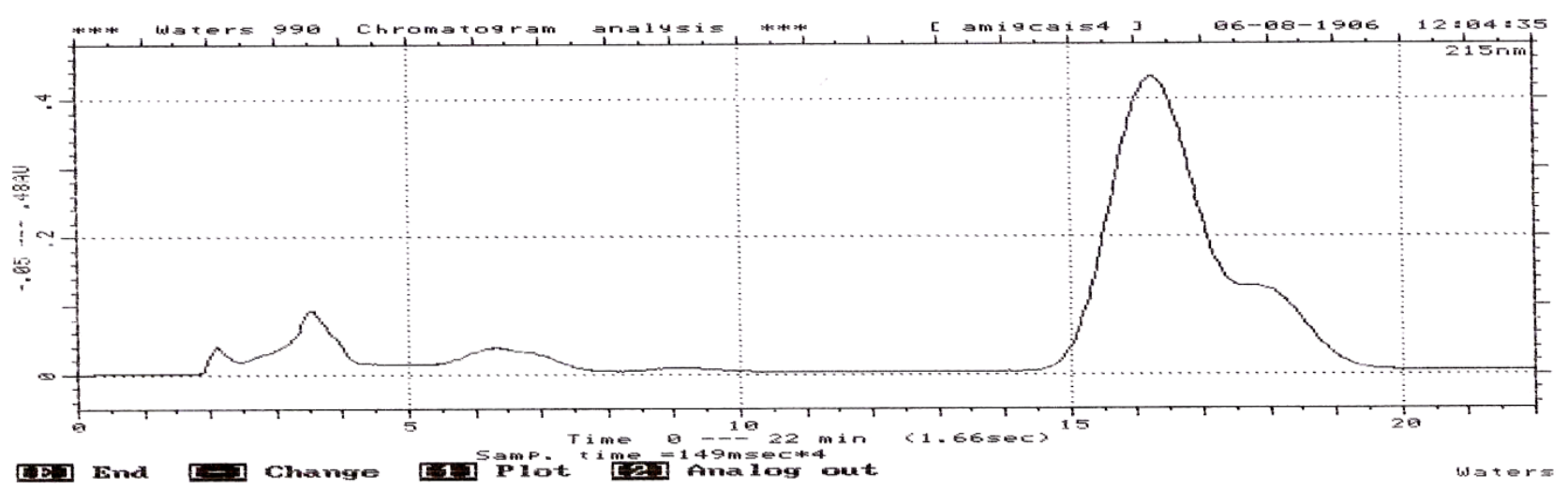

Figure 2 Shows the determination of purity of the amygdaline extract from of the apricot seed extract by HPLC. 


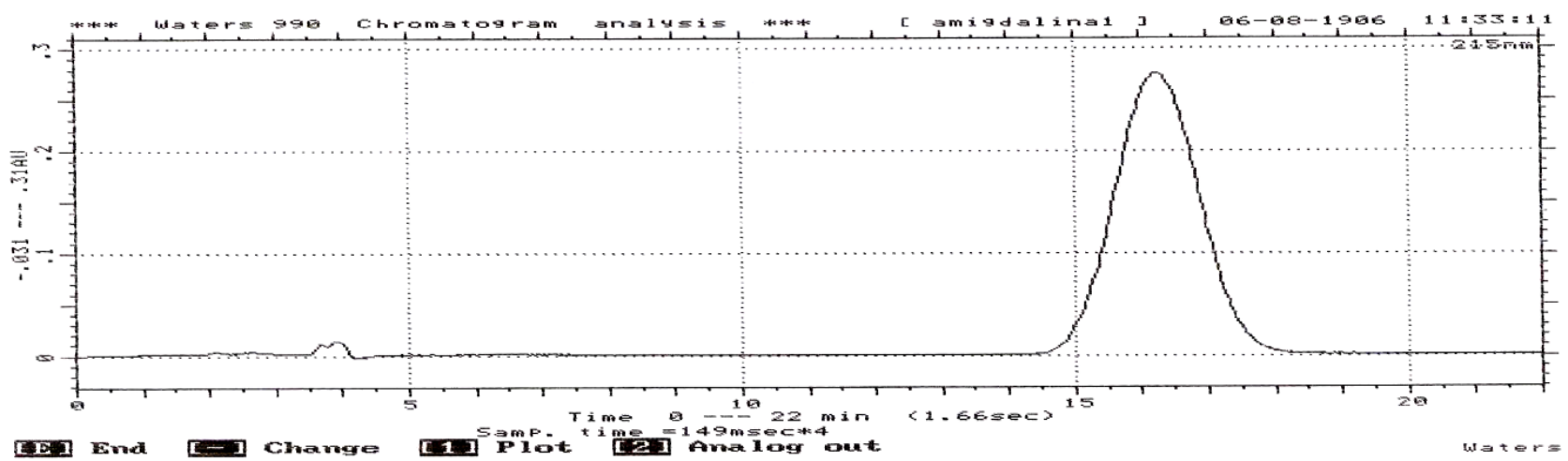

Figure 3 Shows the purity of the standard solution of the amygdaline compound by HPLC.

The level of effectiveness of serum GST and MDA in serum:

In figure (4), we note a decrease in the level of efficiency of GST and MDA in the treated group with $150 \mathrm{mg} / \mathrm{kg}$ of water extract of amygdaline compared with CCL4 (3.2 mg / $\mathrm{kg})(15)$. Either in the treaded group with (250 $\mathrm{mg} / \mathrm{kg}$ ) of water extract (for amygdaline). A reduction was observed, more than $150 \mathrm{mg} / \mathrm{kg}$ which is evidence the efficiency of (350 $\mathrm{mg} / \mathrm{kg}$ ) extract was found to be lower in comparison with the previous two groups (16). This is an indication of the effect of increasing the concentration of the extract on the efficiency of GST and MDA note from figure (4).

That the efficiency of GST and MDA may increase when the CCL4 (induced) is compared to the negative group during the dosage period. It is shown that the use of the extract before giving the carbon tetrachloride better than carbon tetrachloride compound (induced) because the body contains antioxidant substances and also helps to increase the body's immunity(17). We note a decrease and improvement in the significance of the enzyme GST and antioxidants MDA, Which is important in the diagnosis of liver damage compared with the untreated group because the amygdaline compound contains highly effective materials against oxidation process (18).

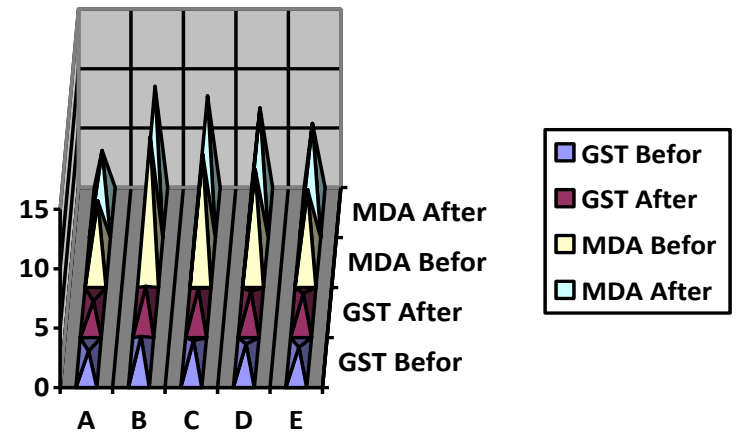

Figure 4 shows the effect of the water extract of amygdaline on the efficiency of GST and antioxidants (MDA) for 14 days before and after the CCLA.

$A=$ negative control (distilled water).

$B=$ positive control CCL4 dose of $3.2 \mathrm{mg} / \mathrm{kg}$.

$C=$ extract with a dose of $(150 \mathrm{mg} / \mathrm{kg})$.

$D=$ extract with dose $(250 \mathrm{mg} / \mathrm{kg})$.

$E=$ extract with a dose of $(350 \mathrm{mg} / \mathrm{kg})$.

\section{Level of liver enzyme efficiency ALT, AST, GGT:}

The result of the study of the effect of three different concentrations of the water extract (for amygdaline) are shown in figures (5) and (6) on the effectiveness of liver enzymes, GGT, ALT, AST) in the blood of laboratory mice before and after the dosage for a period of fourteen days of the dosage to determine the effect articlie CCL4 (Induced). During the duration of the dosage compared to the negative control and positive control models. There were significant differences $(\mathrm{p}<0.01)$. In figures (5) and (6), we note a decrease in the level of enzyme activity (GGT, ALT, AST) in the treated group (150 $\mathrm{mg} / \mathrm{kg}$ ) of water extract (for amygdaline) compared to CCL4 (induced) group. (250 
$\mathrm{mg} / \mathrm{kg}$ ) of the extract was observed with a reduction of more than $150 \mathrm{mg} / \mathrm{kg}$. It was found in the treatment group $(350 \mathrm{mg} / \mathrm{kg}$ ) of the extract was found to be significantly lower than (150 and $250 \mathrm{mg} / \mathrm{kg})$, (19). This is an indication of the effect of increasing the concentration of the water amygdaline extract on enzymatic activity (ALT, AST). Which indicates that there is a more effective effect of the extract of water (for the compound of amygdaline) on enzymes when given before the carbon tetrachloride (induced) and not after (induced) for a period of fourteen days, indicating that the cells were containing an antioxidant and stimulant of enzymes (GGT, ALT, AST) before giving induced (20). The apricot seed contains an effective amygdaline compound that has no harm to proteins that inhibit the enzymes that work together to prevent damage caused by oxidation of cell contents such as nucleic acids, proteins and fats, such as systems that prevent or remove such reactions cause damage to cell contents (21).
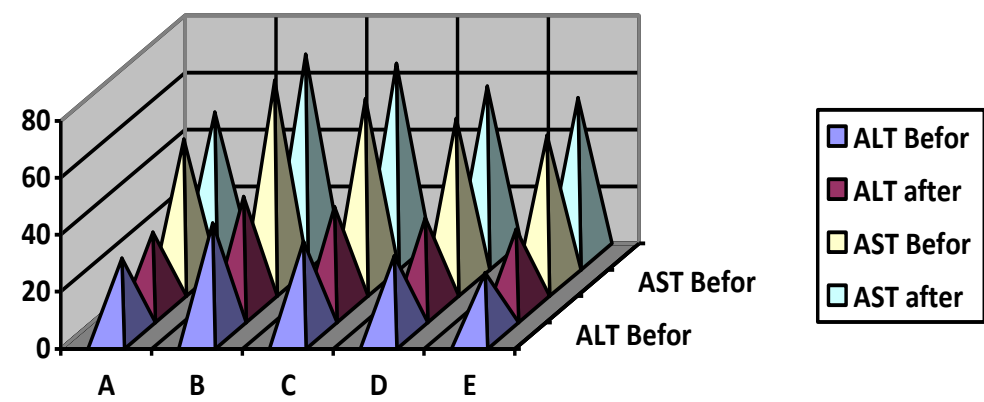

Figure 5 Illustrates the effect of the water extractor of amygdaline compound on the efficiency of AST and ALT enzymes for 14 days before and after the CCL4.

$A=$ negative control (distilled water).

$B=$ positive control CCL4 dose of $3.2 \mathrm{mg} / \mathrm{kg}$.

$C=$ extract with a dose of $(150 \mathrm{mg} / \mathrm{kg})$.

$D=$ extract with dose $(250 \mathrm{mg} / \mathrm{kg})$.

$E=$ extract with a dose of $(350 \mathrm{mg} / \mathrm{kg})$.
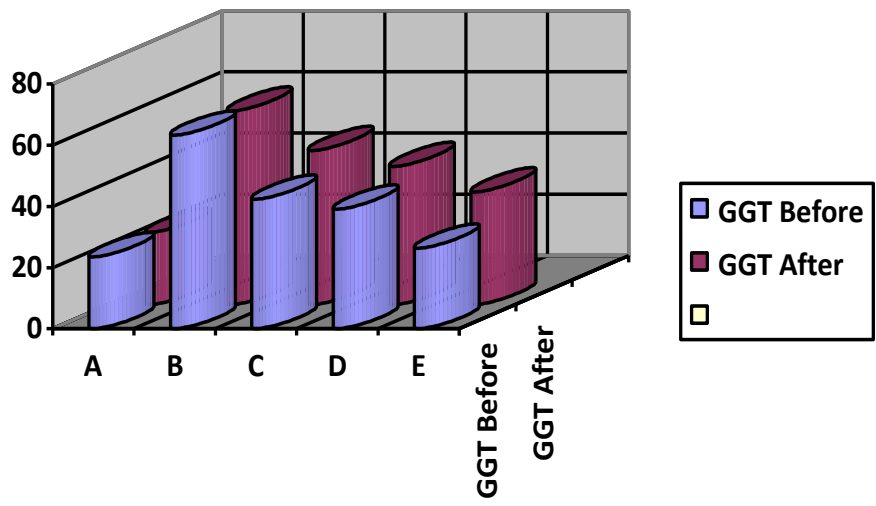

Figure 6 Shows the effect of the water extractor of the amygdaline compound on the efficiency of GGT for 14 days before and after the CCL4.

$A=$ negative control (distilled water).

$B=$ positive control CCL4 dose of $3.2 \mathrm{mg} / \mathrm{kg}$.

$C=$ extract with a dose of $(150 \mathrm{mg} / \mathrm{kg})$.

$D=$ extract with dose $(250 \mathrm{mg} / \mathrm{kg})$.

$E=$ extract with a dose of $(350 \mathrm{mg} / \mathrm{kg})$. 


\section{Effectiveness of liver enzyme ALP and} Billrubin in serum:

The results of the effect study effect of three different concentrations of the water extract of the amygdaline compound are observed in figure (7). on the enzyme ALP and (Billirybin) in the blood of laboratory mice before and after the dosage for a period of fourteen days of the dosage to determine the effect of CCL4 during the duration of the dosage compared with the models negative control and positive control (22). There was a significant difference $(\mathrm{P}<0.01)$ from figure (7). We noticed a decrease in the level of efficiency of ALP, Bilirubin in the group (150 $\mathrm{mg} / \mathrm{kg}$ ) of water extract for (amygdaline) compared with the treated group with CCL4 (induced). Either in the treatment group (250 $\mathrm{mg} / \mathrm{kg}$ ) of the extract was observed with a reduction of more than $150 \mathrm{mg} / \mathrm{kg}$ was observed. Indicating the effectiveness of the extract $(350 \mathrm{mg} / \mathrm{kg})$ was lower in comparison to the group (150and $250 \mathrm{mg} / \mathrm{kg}$ ) (23). This is an indication of the effect of increasing the concentration of the water extract (for amygdaline compound) on the activity and efficiency of the (enzyme ALP, bilirobiun). Which indicates that there is a more effective of water extract (for amygdaline compound) on the enzyme and Billrubin when given before the carbon tetrachloride (induced) and not after (induced) for a period of fourteen days, indicating that the cells were containing an antioxidant and activator of the enzyme ALP, Bilirubin, before giving the induction (24). The amygdaline compound contains effective compounds that have the potential to prevent harm to proteins that inhibit the enzyme and Billrubin, which work together to prevent damage caused by the process of oxidation of the contents of the cell such as nucleic acids, proteins and fat, including systems that prevent the occurrence of these types of interactions or removed before to cause damage to the contents of the cell.

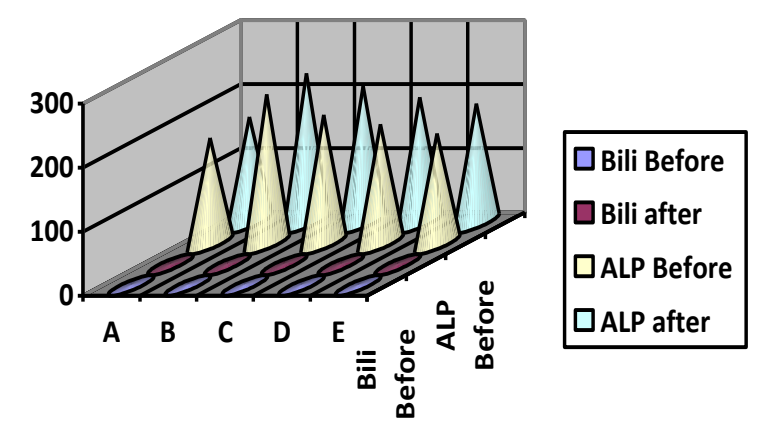

Figure 7 Shows the effect of the water extract of the amygdaline compound on the efficiency of Bilirubin and ALP for 14 days before and after the CCL4.

$A=$ negative control (distilled water).

$B=$ positive control CCL4 dose of $3.2 \mathrm{mg} / \mathrm{kg}$.

$C=$ extract with a dose of $(150 \mathrm{mg} / \mathrm{kg})$.

$D=$ extract with dose $(250 \mathrm{mg} / \mathrm{kg})$.

$E=$ extract with a dose of $(350 \mathrm{mg} / \mathrm{kg})$.

\section{Effectiveness of Cholesterol and Triglyceride in Serum:}

The results of the study of the effect of three different concentrations of the amygdaline compound of water extract are shown in figure (8). On the level of effectiveness of cholesterol and triglycerides in the blood of laboratory mice before and after the dosage for a period of fourteen days of the dosage to determine the effect of CCl4 during the period of the dosage compared with negative control models and, positive control There was a significant difference $(\mathrm{P}<0.01)$ (25) from figure (8).We noticed a decrease in the level of effectiveness of the level of cholesterol and triglyceride activity in the treated group $(150 \mathrm{mg} / \mathrm{kg}$ ) of water (for amygdaline )compared with the treated group CCL4 (induced) group, $(250 \mathrm{mg} / \mathrm{kg})$ of the extract was observed with a reduction of more than $150 \mathrm{mg} / \mathrm{kg}$. The concentration group $(350 \mathrm{mg} / \mathrm{kg}$ ) of the extract was found to be lower in comparison with the group (150 and $250 \mathrm{mg} / \mathrm{kg}$ ) (26). This is an indication of the effect of increasing the concentration of the water extract for amygdaline on the activity and effectiveness of cholesterol and triglycerides. Which indicates that there is a more effective effect of the extract of water for amygdaline on the level of cholesterol and triglyceride when given before carbon tetrachloride (induced) and not after (induced) 
for a period of fourteen days period, indicating that the cells contained an antioxidant and stimulant from cholesterol and triglycerides level of efficiency before giving induced (27).

That the compound amygdaline contains effective compounds have the ability to do no harm to proteins that inhibit the level of effectiveness of cholesterol and triglycerides, indicating the efficiency of amygdaline, which inhibits the free radicals that affect the mechanism of liver function, which causes hormonal imbalance, leading to increased activity fatty protein (28).
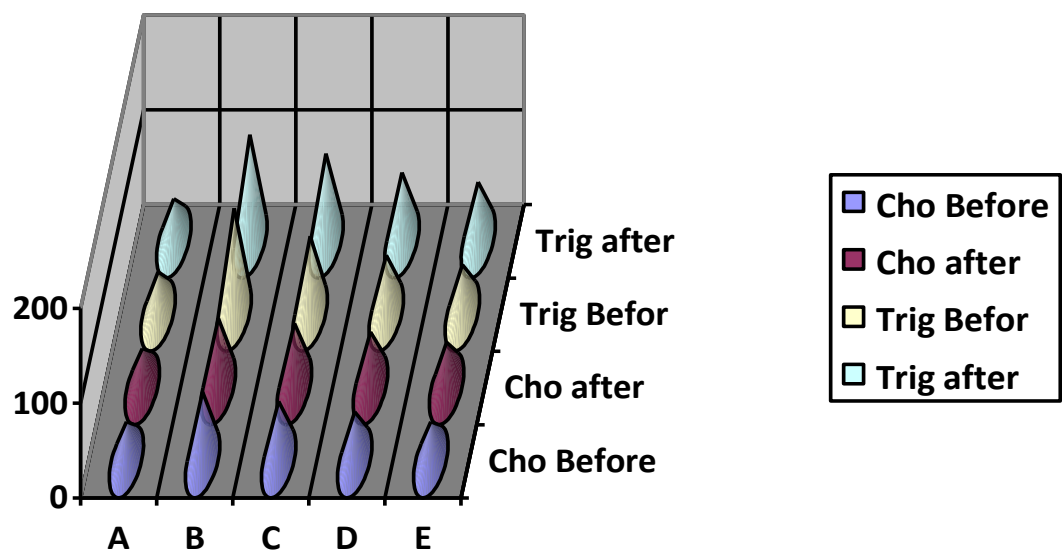

Figure 8 illustrates the effect of the water extractor of the amygdaline compound on the efficiency of cholesterol and triglycerides for 14 days before and after the CCLA.

$A=$ negative control (distilled water).

$B=$ positive control CCL4 dose of $3.2 \mathrm{mg} / \mathrm{kg}$.

$C=$ extract with a dose of $(150 \mathrm{mg} / \mathrm{kg})$.

$D=$ extract with dose $(250 \mathrm{mg} / \mathrm{kg})$.

$E=$ extract with a dose of $(350 \mathrm{mg} / \mathrm{kg})$.

\section{Conclusions}

The results of the study show that the high concentrations of the extract of water to the compound of amygdaline have benefits of high value and it is recommended to avoid the negative health effects caused by pollutants, including carbon tetrachloride because it. contains flavones as well as essential active substances to control the effectiveness of some biochemical and antioxidant changes because it contains bio flavones in treated and non-treated laboratory animals compared with control animals.

\section{References}

(1) F. Gunstone; "Speciality oils of vegetable origin"; Ind. Food Ingred.; (3), 51-54, (1994).

(2) Lv. Wei-Feng, D. Ming-Yu, Z. Rui, "Isolation and Quantitation of Amygdalin in Apricot-Kernel and prunus by HPLC with solid-phase extraction", J. of Chromat. Scie., Vol. 43, 59,63, (2007).
(3) K.Ja-Yong, H. Eun-Young, C. Sonhae, L. Je-Hyun, and L. Yong-Moon, "Quantitative determination of amygdalin epimers from armeniacae semen by liquid chromatography"; Journal of Chromatographic; (814) 69-73, (2005).

(4) A. Garcia, C. Biofísica. São Paulo; Sarvier, (1998).

(5) G. B. Saha, "Fundamentals of Nuclear Pharmacy"; $5^{\text {th }}$ ed. New York: SpringerVerlag, (2005).

(6) A. Perkins, M. Frier; Nuclear Medicine Pharmaceutical Research.1th ed. London: Taylor \& Francis; 178, (1999).

(7) S. V. Singh, G. Creadon, M. Das, H. Mukhtar, and Y. C. Awasthi, "Glutathione-S-transferases of mouse lung selective binding of benzo(a)pyrene metaboliter by the subunit which are preferentially by t-butylated hydroxyanisole"; Biochem. J.; (243), 351-348(1987).

(8) D. R. Spitz, E. I. Azzam, J. J. Li, D. Gius, "Metabolic oxidation/reduction reactions 
and cellular responses to ionizing radiation: A unifying concept in stress response biology"; Cancer Metast. Rev.; (23); 311, 322 (2004).

(9) J.M. Gutteridge and C.E. Cross, "Free radical's antioxidants and human disease"; J. Lab. Clin. Med.; (119) 598, 620 (1992).

(10) C. J. Weydert,, J. J.; "Cullen Measurement of superoxide dismutase, catalase and glutathione peroxidase in cultures cells and tissue"; Nat. Protoc; (5), 51, 66, ( 2010).

(11) K. D. Held, H. Willer; "Molecular and Cellular Basis of Radiation Injury. In Human Radiation Injury"; Shrieve, D.C., Loeffler, J.S., Eds.; Lippincott Williams \& Wilkins, Wolters Klumer: Philadelphia, PA, USA; Volume (1), 1,13 (2011).

(12) A. S. Nada; "Modulating efficacy of rosemary extracts in ratsexposed to oxidative stress". Egypt. J. Rad. Sci. Applic.; 21(2), 499, 514 (2008).

(13) J. Limon-Pacheco, M.E. Gonsebatt, "The role of antioxidants and antioxidant-related enzymes in protective responses to environmentally induced oxidative stress", Mutat. Res.; (674), 137,147 (2009).

(14) U. P. Bhosate, BV Hallale; Asi., J. Pl. Sci.Res; 1(2), 96,100 (2011).

(15) M. Tognolini, E. Barocelli, V. Ballabeni, R.Bruni, A. Bianchi, M. Chiavarini, and M. Impicciatore, "Comparative screening of plant essential oils: phenylpropanoid moiety as basic core for antiplatelet activity", Life Sci.; 78 (13), 1419,1432 (2006).

(16) K. M. El-Azony; J. Radioanal. Nucl. Chem.; 285, 320 (2010).

(17) Francoise, C., Pierre, M. Jacqueline, R. and Henri, J. (1989) Chemical clinical, Acta ; 209-217.

(18) A. Belfield, and D.M. Goldberg, "Revised assay for serumphenyl phosphatase activity using4-aminoantipyrine". Enzyme; 12, (5), 561, 586, (1971).

(19) K. L. Fong, P.B. McCay and J. L. Poyer; J. Bio. Chem. 248, 7792, 7(1973).
(20) W.F.Balistreri,L.M.Shaw, "Liver function in fundamentals of vlinical chemistry"; Teitz, N.W.(ed.) 3rded. W. B. Saunders company, Philadelphia; 729, 760 (1987).

(21) B.T.Doumas,W.A.Watson, and H.G.Biggs; "Albumin standards and the measurement of seum albumin with bromcresol green", J.Clin. Chem.Acta.; 31,(1);87,89(1971).

(22) M. Xingjum, Z. Zhong, Z. Hailan, LiMing AND Z. Qingxia, "Comparison of second- derivative apectrophotometry HPLC", J. of Bio Scie. 3(1), 73, 83,(2013).

(23) J. Mahwah, S. Mary am, Z. Homerira and F.Rostamkhani, "Response of liver antioxidant defense system to acute and chronic physical and psychological stresses in mice", J. Exc. Li 13, 161,171, (2014).

(24) R. Maithreyi, A. V. Janani, R. Krishna and A. Shwrta, "Erythrocyte lipid peroxidation and antioxidants in chronic with radiation liver disease", Asian Jou.of pharm. And Clin. Res., Vol.(3), 3, 183, 189, (2012).

(25) A Ramesh and R.C. Verma, Journal of Bio. Scie., 4(1), 82,85,(2015).

(26) H. Tominaga, S. Kodama, N. Matsuda, K. Suzuki, and M. Watanabe, "Involvement of reactive oxygen species (ROS) in the induction of genetic instability by radiation", J. Rad. Res., 45(2), 181, 8, (2014).

(27) A. M. Haggag, N. M. El-Beih, and S. A. Mangood, "In vivo internal decontamination of ${ }^{134} \mathrm{Cs}$ and ${ }^{60} \mathrm{Co}$ from male albino rats", Egypt. J. Rad. Sci. Applic., 21(2): 531-546 (2008).

(28) N. R. Madamanchi, and M. S. Runge, "Mitochondrial dysfunction in atherosclerosis", Circul. Res., 100(4), 460, 473 (2007). 